\title{
Didática Desenvolvimental na perspectiva da subjetividade: práticas pedagógicas com foco no sujeito.
}

\author{
Juliana Magalhães de Brito Vianna - Instituto Teresa Valsé \\ Roberto Valdés Puentes - UFU
}

\section{Resumo}

Um dos grandes desafios, no campo da educação, ao longo dos tempos, é buscar práticas pedagógicas que exerçam, dentro dos ambientes escolares, ações mediadoras que levem em conta todos os envolvidos no processo de aprendizagem, ao considerá-los como sujeitos de transformação do meio e de si próprios. Até o presente momento, as práticas pedagógicas hegemônicas, têm focado no conteúdo ou nos métodos, esquecendo com isso o sujeito desse processo. O presente trabalho procura abordar uma concepção didática que, mesmo voltada para o desenvolvimento dos alunos, supere a concepção determinista e mecânica da Didática Desenvolvimental da Atividade ao considerar como fundamental, na prática pedagógica, a constituição subjetiva dos estudantes. A Didática Desenvolvimental da Atividade, concebida no final da década de 1950, na ex-União Soviética, colocou em prática as teses de Vigotski (2010) sobre a relação recíproca entre aprendizagem e desenvolvimento, ao elaborar um modelo que procurava atingir o resultado ótimo na formação dos escolares (PUENTES; AQUINO, 2019). Contudo, privilegiou o desenvolvimento psíquico (especialmente, o pensamento teórico - conceitos científicos e modos generalizados de ação), em detrimento do subjetivo (PUENTES, 2019); assumiu uma postura determinista com respeito à relação entre a atividade objetiva (externa) e subjetiva (interna); compreendeu a atividade de estudo enquanto processo de interiorização dos conhecimentos, negando com isso o caráter gerador e criativo do sujeito que aprende; privilegiou o caráter cognitivista dos processos didáticos, ignorando a unidade do simbólico e do emocional na constituição da subjetividade; negou o aluno como sujeito de sua própria atividade (PUENTES; CARDOSO; AMORIM, 2018). A Teoria da Subjetividade de González Rey (1997, 2005, 2017), vista no contexto das práticas pedagógicas escolares, remete a ideia de que a organização adequada dos processos de aprendizagem não leva necessariamente ao desenvolvimento desejado dos estudantes, porque, mesmo existindo uma relação de reciprocidade entre o desenvolvimento da personalidade e as práticas didáticas que realizam, essa não é determinista. A aprendizagem é definida como uma real personalização do aprendido que permite ao 
aluno sua utilização em situações novas e sua integração com outros conhecimentos e experiências que ampliem suas representações ou que gerem ideias e ações que vão além do que foi apresentado (MITJÁNS MARTÍNEZ; GONZÁLEZ REY, 2017, p. 60). O desenvolvimento, por sua vez, é entendido como o processo de formação de novos recursos subjetivos que permitem ao indivíduo mudanças qualitativas em áreas diversas da vida e que geram um envolvimento pessoal cada vez mais profundo na área em que a configuração subjetiva do desenvolvimento se organiza. A ideia é organizar, com a participação dos alunos, um tipo específico de atividade de estudo que permita, ao mesmo tempo, o desenvolvimento de suas capacidades psíquicas e subjetivas, acreditando em sua força criadora para a produção de sentidos e configurações que levam a elaboração de recursos subjetivos que são fruto e fonte da atividade e do próprio sujeito dela.

Palavras-chave: Didática Desenvolvimental; Subjetividade: Práticas Pedagógicas.

\section{Referências}

GONZÁLEZ REY, F. L. Sujeito e subjetividade: uma aproximação histórico-cultural. São Paulo: Pioneira Thomson Learning, 2005

GONZÁlEZ REY, F. L.; MITJÁNS MARTÍNEZ, A. Subjetividade: teoria, epistemologia e método. Campinas: Alínea, 2017.

GONZÁLEZ REY, Fernando Luis González. Epistemología cualitativa y subjetividad. 1. ed. São Paulo: EDUC, 1997, v. 1, 387p.

MITJÁNS MARTÍNEZ, A.; GONZÁLEZ REY, F. L. Psicologia, educação $e$ aprendizagem escolar: avançando na construção da leitura cultural-histórica. São Paulo: Cortez Editora, 2017.

PUENTES, Roberto Valdés. A noção de sujeito na concepção de aprendizagem desenvolvimental: uma abordagem à luz da teoria da subjetividade. Obutchénie, Uberlândia, v. 3, n. 1, p. 1-30, 2019 (em avaliação).

PUENTES, Roberto Valdés; AQUINO, Orlando Fernández. Ensino desenvolvimental da atividade: uma introdução ao estudo do sistema zankoviano (19571977). Linhas Críticas, Brasília, DF, v. 24, p. 342-366, 2019. Disponível em $<<$ http://periodicos.unb.br/index.php/linhascriticas/article/view/20106/20633>>. Acesso em 12/07/2019.

PUENTES, Roberto Valdés; CARDOSO, Cecília Garcia Coelho; AMORIM, Paula Alves Prudente. A atividade de estudo segundo V. V. Repkin: uma abordagem crítica na 
perspectiva da subjetividade. Ensino em Re-vista, Uberlândia, v. 25, n. 3, p. 766-789, 2018. Disponível

em $<<$ http://www.seer.ufu.br/index.php/emrevista/article/view/45941/24568>>. Acesso em 12/07/2019.

VIGOSTKI, Lev. S. Aprendizagem e desenvolvimento na idade escolar. In: Linguagem, desenvolvimento e aprendizagem. Vigostky, L. Luria, A. Leontiev, A.N. 11ª Edição. São Paulo: Ícone, 2010, p. 103-117. 